\title{
Face validity of the general development assessment test (EVADE) in children and adolescents aged 6-14 years
}

\author{
Ana M. Quezada-Ugalde* y Sunny González-Serrano \\ Universidad de Costa Rica, San José, San Pedro, Costa Rica
}

\begin{abstract}
Background: The general development assessment test (EVADE) for children and adolescents aged 6-14 years is the only national screening tool for development assessment of school-age children and adolescents. This article presents the results obtained after applying the face validity process to the test, the handbook, and the standardized materials. Methods: An exploratory, descriptive study was conducted with a quantitative-qualitative methodology. The EVADE test was applied to a sample of 730 children and adolescents between 6 and 14 years of age, for which the expert judgment technique was used. Data analysis was carried out through a psychometric analysis of the items and by the triangulation method. Results: From the 730 participants included, $44.5 \%$ were from rural areas $(n=325)$ and $55.4 \%$ from urban areas $(n=405)$, of which $51.7 \%$ $(n=378)$ of females and $48.2 \%(n=352)$ of males were assessed by the test. The difficulty level and discriminative effectiveness quotient of the items were calculated, which, together with the experts' findings, resulted in 22-item modifications and the creation of four new items in the cognitive and language areas. The qualification by areas also changed, improving the handbook and creating new materials. Conclusions: This research provides a validated screening test for the child and adolescent population, which was included in the Costa Rican comprehensive childcare public policy. However, subsequent validation processes are recommended to improve specific areas, such as motor skills and social-affective development.
\end{abstract}

Key words: Child and adolescent development. EVADE test. Screening tool. Validation.

\section{Validación de apariencia de la prueba general para la evaluación del desarrollo (EVADE) en niños, niñas y adolescentes entre los 6 y 14 años}

\section{Resumen}

Introducción: La prueba general para la evaluación del desarrollo (EVADE) para niñas, niños y adolescentes entre 6 y 14 años es la única prueba a nivel nacional que valora el desarrollo en población escolar y adolescente. Este artículo presenta los resultados tras someter la prueba, el instructivo y los materiales estandarizados al proceso de validación de apariencia. Métodos: Se llevó a cabo un estudio descriptivo exploratorio, con metodología cuantitativa-cualitativa. La prueba EVADE se aplicó a una muestra de 730 niñas, niños y adolescentes entre 6 y 14 años; asimismo, se utilizó la técnica de juicio de expertos. El análisis de los datos se efectuó a través de un análisis psicométrico de los enunciados y triangulación.

Disponible en internet: 13-11-2019 Bol Med Hosp Infant Mex. 2019;76:273-280 www.bmhim.com 
Resultados: De los 730 participantes, el $44.5 \%$ correspondió a zonas rurales $(n=325)$ y el $55.4 \%$ a zonas urbanas $(n=405)$. El $51.7 \%$ de ellos eran de sexo femenino $(n=378)$ y el $48.2 \%$, de sexo masculino $(n=352)$. Se calculó el nivel de dificultad y el coeficiente de efectividad discriminativa para los enunciados. A la par de los hallazgos referidos por los expertos, resultó en la modificación de 22 enunciados, la creación de cuatro nuevos artículos en las áreas cognitiva y de lenguaje. También se cambió la calificación por áreas, se mejoró el instructivo y se crearon nuevos materiales. Conclusiones: La presente investigación aporta una prueba validada para la población infantil escolar y adolescente, que fue incluida en la política pública de atención integral de la población infantil costarricense. Se recomiendan procesos de validación subsecuentes con el fin de mejorar áreas específicas, como motricidad y socioafectiva.

Palabras clave: Desarrollo infantil y adolescente. Estudio de validación. Prueba EVADE. Tamizaje.

\section{Introduction}

Some development scales are used at the domestic scale, such as the EDIN-II (General Child Comprehensive Assessment Test for children aged 0 months-6 years) and the Denver II, an American test adapted for Spanish-speaking populations, which is intended for children aged 1 month-6 years.

For the assessment of the development of children > 6 years of age in Costa Rica, the Development Evaluation Test (EVADE) is the only instrument available, which is applied nationwide in children and adolescents aged 6-14 years since 2000 (the first edition of the test). EVADE assesses the areas of gross and fine motor skills, cognitive, language, and social-affective development. Among its instruments are included assessment items, a handbook for the correct application of the test and standardized materials ${ }^{1}$. However, it is necessary to identify its face validity, to state that the test "seems to measure what it ought to measure 2 ." For this study, face validity was determined through the application of the test to children and adolescents from several rural and urban areas from around the country.

Although human development is understood as the progressive construction of a building, which structure and foundation are laid down during the first 6 years of life ${ }^{3}$, it is of the utmost importance to continue the development assessment after 6 years of age, as the greater control and the learning process - characteristic to school and adolescent years - are big consolidation domains in terms of the so-called areas of development ${ }^{4}$.

As the EVADE test assesses the child population > 6 years of age and extends its assessment up until 13 years, 11 months, and 29 days, it includes the stages of middle or young childhood and early adolescence. Middle childhood extends from the ages of 6 to 11 years. Among its physical and developmental characteristics are a slowing down of the growing process (height), a significant increase in sports skills and strength, an increase in memory and language skills, and an evolution from illogical reasoning to logical and concrete thinking ${ }^{5}$.

Early adolescence includes the period from the ages of 10 to 14 years. This stage witnesses the manifestation of physical signs of puberty: a sudden increase in linear growth (height) and the development of sex organs and secondary sex characteristics ${ }^{6}$. Abstract thinking and scientific reasoning develop in this stage, which prepares the adolescent for any future formal training ${ }^{5}$.

Furthermore, development assessment in children and adolescents is a process aimed to identify the maturity level attained by the children in comparison to their age group for the identification of possible alterations and the establishment of a monitoring plan, which enables to heighten their strengths and diminish their weaknesses along with the various areas evaluat$\mathrm{ed}^{2}$. Early detection of developmental problems is of the utmost importance for the well-being of the children and their families, as it facilitates early diagnosis and treatment.

With this in mind, the general goal of this study was to determine the face validity of the general development assessment test (EVADE) in children and adolescents aged 6-14 years in rural and urban areas of Costa Rica.

\section{Methods}

A descriptive-exploratory study was conducted, with a quantitative-qualitative methodology that enables a picture of the studied phenomenon as a whole 7 . The sample defined was 730 children and adolescents aged 6-14 years, who were current students from public schools or high schools around the country. The sample met the following inclusion criteria ${ }^{8}$ : to accept participation in the test (informed assent and consent), not suffering from any illness during the test, being free of any physical or cognitive disability, and belonging to 
one of the age groups at the moment of the application of the test.

The EVADE was created by one of the researchers in 1995. This test is composed of five domains, one for each area of development: gross and fine motor, cognitive, language, and socioaffective. Three items compose each domain by age group. Each item is evaluated as positive or negative; the score equals the total of positive items with a range from 0 to 3 . A team of four researchers and 50 applicators previously trained applied the test. For data collection, the following instruments were used:

1. Qualitative capture of the items: in this instrument, the evaluator must record the child's understanding of the language used, the usefulness of the materials, and the manual.

2. Quantitative capture of test scores: describes the score obtained by the child or adolescent. If the child scores 2 or 3 points for each area, he/she is located with an appropriate development for their age; conversely, if the child scores 0 or 1 point, it is necessary to apply the items of the previous age to determine the risk of developmental delay.

In addition, an expert judgment technique following the consensus method was used for complementing the qualitative capture. The consensus consists of a discussion group where previously chosen experts reunite in one or more sessions and look for an agreement on the researched phenomenon ${ }^{7}$. During this research process, the following stages were implemented:

a. A collaboration of experts from two institutions in Mexico City: Development Unit at the Hospital Infantil de México Federico Gómez and Neurodevelopment Monitoring Laboratory at the Instituto Nacional de Pediatría for the revision of the test.

b. Coordination of face-to-face sessions where items, difficulty level, and advisability by age groups, among other issues, were discussed.

c. The research team traveled to Mexico, where analysis meetings about test items according to the development areas and age groups were held.

d. Analysis of the data according to the insights received.

To obtain expert judgment, two consensus sessions were made with three experts from the Hospital Infantil de México Federico Gómez, a neurologist, psychologist, and a physiatrist, and two consensus sessions at the Neurodevelopment Monitoring Laboratory of the Instituto Nacional de Pediatría, with four experts: a neurologist, a linguist, and two developmental psychologists. The purpose of the discussions was the analysis of every item of the gross and fine motor, language, cognitive, and social-affective areas. Findings from the test application and the sessions with experts allowed for the second edition of the EVADE test.

Statistical analysis of the data was performed through a psychometric analysis, determining the difficulty level, and discrimination quotient of every item. Qualitative analysis was made through triangulation of data collected by developmental experts, with remarks on the items, materials, and the handbook for the correct application of the test, theoretical references, and the researchers' experience (field notes) ${ }^{9}$. As a result, several changes and improvements were made for EVADE-II.

\section{Ethical guidelines}

During the research, the Ethical-Scientific Regulations of the Universidad de Costa Rica ethical guidelines were considered ${ }^{10}$. The principles considered were autonomy, good deeds, no wrongdoing, and justice. Furthermore, informed consent by every person responsible for the participants and informed assent by adolescents older than 12 years of age were required.

\section{Results}

The study was applied to 730 children and adolescents aged 6-14 years, distributed among rural $(n=325 / 44.5 \%)$ and urban $(n=405 / 55.4 \%)$ areas of the country. Sorted by sex, $n=378(51.7 \%)$ tests were applied to females and $n=352(48.2 \%)$ to males. In addition, the number of applications by age group remained as even as possible: 6 years, $16.5 \%(n=120)$; 7 years, $19.2 \%(n=140) ; 8$ years, $16.5 \%(n=121)$; 9 years, $18.5 \%(n=135) ; 10-11$ years, $14.7 \%(n=108)$; and $12-13$ years, $14.6 \%(n=106)$.

The test application process was performed in two steps: first, a collection of 603 tests; after - due to data saturation - a first statistical analysis was performed, and the data were triangulated with the remarks made by the teams of experts, the insights and the theoretical component written down by the researchers during the test application.

This process determined the need for a significant number of changes to the EVADE test as well as writing new statements for it. The motor skills and social-affective areas needed no changes, while the language and cognitive areas received 22 changes in statements and materials, and four new items were included - with their respective adaptations to the handbook and materials. 
Table 1. Discrimination quotient and difficulty level results of gross and fine motor skills items by age in the EVADE test

\begin{tabular}{|l|c|c|c|c|c|c|c|}
\hline \multicolumn{3}{|c|}{ First collection } & \multicolumn{3}{c|}{ Second collection } \\
\hline $\begin{array}{l}\text { Area/ } \\
\text { item }\end{array}$ & dl & deq & SD & $\begin{array}{c}\text { Area/ } \\
\text { item }\end{array}$ & dl & deq & SD \\
\hline \multicolumn{5}{|c|}{$\mathbf{6}$ years-6 years 11 } & months 29 days \\
\hline GM.1 & 0.91 & 0.62 & 0.29 & GM.1 & 0.95 & 0.89 & 0.22 \\
\hline GM.2 & 0.90 & 0.38 & 0.30 & GM.2 & 0.90 & 0.69 & 0.31 \\
\hline GM.3 & 0.99 & 0.19 & 0.10 & GM.3 & 0.90 & 0.54 & 0.31 \\
\hline FM.1 & 0.83 & 0.27 & 0.38 & FM.1 & 0.80 & 0.71 & 0.41 \\
\hline FM.2 & 0.91 & 0.16 & 0.29 & FM.2 & 0.85 & 0.47 & 0.37 \\
\hline FM.3 & 0.87 & 0.22 & 0.34 & FM.3 & 0.80 & 0.63 & 0.41 \\
\hline & 7 & years-7 years 11 months 29 days & \\
\hline GM.1 & 0.96 & 0.13 & 0.20 & GM.1 & 0.90 & 0.58 & 0.31 \\
\hline GM.2 & 1 & 0 & 0 & GM.2 & 0.97 & 0.78 & 0.16 \\
\hline GM.3 & 0.96 & 0.49 & 0.20 & GM.3 & 0.85 & 0.44 & 0.37 \\
\hline FM.1 & 0.86 & 0.31 & 0.35 & FM.1 & 0.69 & 0.44 & 0.47 \\
\hline FM.2 & 0.98 & 0.26 & 0.14 & FM.2 & 1 & 0 & 0 \\
\hline FM.3 & 0.99 & 0.20 & 0.10 & FM.3 & 0.90 & 0.72 & 0.31 \\
\hline
\end{tabular}

\begin{tabular}{|l|c|c|c|c|c|c|c|}
\hline \multicolumn{7}{|c|}{8 years-8 years 11 months 29 days } \\
\hline GM.1 & 0.94 & 0.09 & 0.24 & GM.1 & 0.95 & 0.38 & 0.22 \\
\hline GM.2 & 0.77 & 0.22 & 0.42 & GM.2 & 0.33 & 0.21 & 0.48 \\
\hline GM.3 & 0.88 & 0.20 & 0.33 & GM.3 & 0.95 & 0.38 & 0.22 \\
\hline FM.1 & 0.98 & 0.33 & 0.14 & FM.1 & 0.86 & 0.39 & 0.36 \\
\hline FM.2 & 0.66 & 0.47 & 0.48 & FM.2 & 0.33 & 0.28 & 0.48 \\
\hline FM.3 & 0.92 & 0.42 & 0.27 & FM.3 & 0.90 & 0.65 & 0.30 \\
\hline & 9 & years-9 years 11 months 29 days & & \\
\hline GM.1 & 0.98 & 0.25 & 0.14 & GM.1 & 0.91 & 0.82 & 0.28 \\
\hline GM.2 & 0.97 & 0.26 & 0.17 & GM.2 & 0.94 & 0.52 & 0.24 \\
\hline GM.3 & 1 & 0 & 0 & GM.3 & 0.05 & 0.05 & 0.24 \\
\hline FM.1 & 0.97 & 0 & 0.17 & FM.1 & 0.88 & 0.42 & 0.32 \\
\hline FM.2 & 1 & 0 & 0 & FM.2 & 0.94 & 0.78 & 0.24 \\
\hline FM.3 & 0.99 & 0.10 & 0.10 & FM.3 & 0.97 & 0.68 & 0.17 \\
\hline & 10 years-11 years 11 months 29 days & \\
\hline GM.1 & 0.96 & -0.00 & 0.19 & GM.1 & 1 & 0 & 0 \\
\hline GM.2 & 0.97 & 0.27 & 0.17 & GM.2 & 1 & 0 & 0 \\
\hline GM.3 & 0.90 & 0.23 & 0.29 & GM.3 & 0.83 & 0.41 & 0.41 \\
\hline FM.1 & 0.88 & 0.10 & 0.32 & FM.1 & 1 & 0 & 0 \\
\hline
\end{tabular}

Table 1. Discrimination quotient and difficulty level results of gross and fine motor skills items by age in the EVADE test (continuation)

\begin{tabular}{|l|c|c|c|c|c|c|c|c|}
\hline \multicolumn{4}{|c|}{ First collection } & \multicolumn{4}{c|}{ Second collection } \\
\hline $\begin{array}{l}\text { Area/ } \\
\text { item }\end{array}$ & dl & deq & SD & $\begin{array}{c}\text { Area/ } \\
\text { item }\end{array}$ & dl & deq & SD \\
\hline \multicolumn{5}{|c|}{$\mathbf{6}$ years-6 years 11 months 29 days } \\
\hline FM.2 & 0.80 & 0.13 & 0.39 & FM.2 & 0.83 & 0.41 & 0.41 \\
\hline FM.3 & 0.99 & 0.06 & 0.09 & FM.3 & 1 & 0 & 0 \\
\hline & 12 & years-13 years 11 months 29 days & \\
\hline GM.1 & 0.99 & 0.02 & 0.10 & GM.1 & 1 & 0 & 0 \\
\hline GM.2 & 0.97 & 0.29 & 0.17 & GM.2 & 1 & 0 & 0 \\
\hline GM.3 & 1 & 0 & 0 & GM.3 & 1 & 0 & 0 \\
\hline FM.1 & 0.97 & 0.09 & 0.17 & FM.1 & 1 & 0 & 0 \\
\hline FM.2 & 0.76 & 0.34 & 0.43 & FM.2 & 1 & 0 & 0 \\
\hline FM.3 & 0.91 & 0.21 & 0.29 & FM.3 & 0.83 & 0.81 & 0.41 \\
\hline
\end{tabular}

GM: gross motor skills items; FM: fine motor skills items; dl: difficulty level; deq: discriminatory effectiveness quotient; SD: standard deviation

Therefore, the second data collection (to complete the sample) consisted of the application of the EVADE second version, with a total of $n=127$ children and adolescents.

In both applications, the difficulty level (dl) and the discrimination effectiveness quotient (deq) were determined (Tables 1-4 detail the obtained data for each area of development).

Some examples of the changes are the modification of words in the memory items, changes in reading texts for the evaluation of pragmatics skills, and incorporation of analog lists to assess logical relationships at different ages. These modifications respond to the need to increase difficulty levels and the ability to identify the language and cognition skills of the items.

The findings of the second application confirmed the pertinence of the changes, as a meaningful increase was found in the difficulty level of the items and the discrimination level of developmental skills in 18 of 36 language and cognitive items. Ten other items maintained a good or excellent discrimination quotient, and a smaller number of items will require further assessment in later research studies.

As a last facet, the EVADE-II test was also modified in its scoring system, leaving only the assessment by areas of development (gross and fine motor skills, cognitive, language, and social-affective development), instead of a global assessment, as previously done. 
The rigor and reflexivity ${ }^{9}$ of the study respond to the credibility criteria, through the constant reflection of the researchers in their field journals. Technical sessions were held to consider the findings and saturation of the data, the confirmability criteria when comparing the study with similar processes carried out by the experts consulted, and the criterion of authenticity, since a responsible investigator reviewed each application of the test.

\section{Discussion}

All the information previously reported about the EVADE test was generated from the findings of a sample of participants included in the face validity study.

EVADE is classified as a screening test, which function is to "identify allegedly ill children and adolescents in a seemingly healthy population by establishing the risk or suspicion of a development issue ${ }^{11}$." This trait determined that it was more convenient to segregate the test score by areas of development. Furthermore, as EVADE-II is an instrument that contemplates ages such as school-age childhood and early adolescence, any individuals who indicate developmental lag will require monitoring by different developmental specialties, according to the support networks available in the health and education sectors.

For example, in the motor skills area, only a motor skills specialist or a physiatrist can address any lag or disorder identified in coordination and balance development. Similarly, if a lag in the language or cognitive areas is found, a transfer to language therapy, psychopedagogy, or to educators is needed to provide minors with appropriate monitoring to their needs.

Finally, for the social-affective development, the scope is so broad that, more than a screening, it becomes an opportunity to deepen the information about personality traits, relationships with their peers, family, and socioeconomic situation of children and adolescents, among other aspects. If the specialist detects any situation requiring a more in-depth assessment, the individual should be referred to a specialist in psychology, social work, or other pertinent disciplines for appropriate monitoring.

Regarding the results on the areas of gross and fine motor skills, it was found that, in every age group, most of the statements got behavior resolution percentages of $85-100 \%$, proving that the population performs the requested tasks without any significant difficulty. During the second data collection, both areas maintained a
Table 2. Discrimination quotient and difficulty level results of cognitive items by age in the EVADE test

\begin{tabular}{|c|c|c|c|c|c|c|c|}
\hline \multicolumn{4}{|c|}{ First collection } & \multicolumn{4}{|c|}{ Second collection } \\
\hline $\begin{array}{l}\text { Area/ } \\
\text { item }\end{array}$ & dl & deq & SD & $\begin{array}{l}\text { Area/ } \\
\text { item }\end{array}$ & dl & deq & SD \\
\hline \multicolumn{8}{|c|}{6 years- 6 years 11 months 29 days } \\
\hline CG.1 & 0.84 & 0.63 & 0.37 & CG.1 & 0.90 & 0.23 & 0.31 \\
\hline CG.2 & 0.99 & -0.09 & 0.10 & CG.2 & 0.95 & 0.89 & 0.22 \\
\hline CG.3 & 0.92 & 0.47 & 0.27 & CG.3 & 1 & 0 & 0 \\
\hline \multicolumn{8}{|c|}{7 years- 7 years 11 months 29 days } \\
\hline CG.1 & 0.85 & 0.54 & 0.36 & CG.1 & 0.82 & 0.35 & 0.39 \\
\hline CG.2 & 0.89 & 0.35 & 0.31 & CG.2 & 0.82 & 0.31 & 0.39 \\
\hline CG.3 & 0.44 & 0.39 & 0.50 & CG.3 & 0.95 & 0.66 & 0.22 \\
\hline \multicolumn{8}{|c|}{8 years-8 years 11 months 29 days } \\
\hline CG.1 & 0.92 & 0.62 & 0.27 & CG.1 & 0.81 & 0.67 & 0.40 \\
\hline CG.2 & 0.94 & 0.63 & 0.24 & CG.2 & 0.67 & 0.66 & 0.48 \\
\hline CG.3 & 0.36 & 0.29 & 0.48 & CG.3 & 0.66 & 0.55 & 0.36 \\
\hline \multicolumn{8}{|c|}{9 years -9 years 11 months 29 days } \\
\hline CG.1 & 0.41 & 0.31 & 0.49 & CG.1 & 0.85 & 0.27 & 0.36 \\
\hline CG.2 & 0.45 & 0.38 & 0.50 & CG.2 & 0.62 & 0.45 & 0.49 \\
\hline CG.3 & 0.90 & 0.31 & 0.30 & CG.3 & 0.22 & 0.06 & 0.43 \\
\hline \multicolumn{8}{|c|}{10 years-11 years 11 months 29 days } \\
\hline CG.1 & 0.76 & 0.50 & 0.42 & CG.1 & 0.83 & 0.81 & 0.41 \\
\hline CG.2 & 0.85 & 0.41 & 0.35 & CG.2 & 0.83 & 0.81 & 0.41 \\
\hline CG.3 & 0.78 & 0.54 & 0.41 & CG.3 & 0.67 & 0.97 & 0.52 \\
\hline \multicolumn{8}{|c|}{12 years-13 years 11 months 29 days } \\
\hline CG.1 & 0.78 & 0.40 & 0.42 & CG.1 & 0.83 & 0.81 & 0.41 \\
\hline CG.2 & 0.27 & 0.46 & 0.45 & CG.2 & 0.33 & 0.59 & 0.52 \\
\hline CG.3 & 0.89 & 0.40 & 0.31 & CG.3 & 0.67 & 0.93 & 0.52 \\
\hline
\end{tabular}

CG: cognitive items; dl: difficulty level; deq: discriminatory effectiveness quotient; SD: standard deviation.

similar behavior: percentages of $85-100 \%$ were attained, and discrimination values remained at great or excellent motor skills discriminatory power.

Furthermore, every age group has statements fluctuating between good, regular, or low statistical discrimination levels (Table 1), inciting the suggestion of conducting a research process exclusive to these areas, in collaboration with experts in motor development, physical education, physiatry, and other related disciplines. 
The cognitive area was among the most assessed. Significant changes to the items were made, causing improvements in component delimitation. For example, one statement for the first age group, which assesses short-term memory, included bilabial items ending in the letter "a," facilitating the task. A new list of words from different semantic fields was established, enabling children to repeat them using meaning recollection and conceptual links ${ }^{12}$.

Some changes were made to the component quantity concept and conservation. Additional tasks were added, enabling not only an increased difficulty level but also that the participants think of the proposed quantities as a permanent whole, independent from changes in the form or position of their parts ${ }^{5,13,14}$.

It is worth mentioning that the items produced for the cognitive area are repeated in different age groups, but with increasing difficulty levels, to determine if the child's development continues as their teaching-learning level increases. Some examples are the statements that assess the logical relationships component ${ }^{15}$ through a list of analogies. Similarly, for the memory and association component ${ }^{16}$, assessed by a group of inquirers who ask for a description of similarities between the mentioned objects, and for the arithmetic calculation component ${ }^{17,18}$, which includes mathematical problems extracted from the Costa Rican Ministry of Public Education curricula.

On completion of the EVADE-II pilot, the relevance of the changes or new proposals previously mentioned was confirmed, as the items with regular or proper discrimination quotients increased to an excellent cognitive skills discrimination quotient. As well, their solution percentages showed appropriate difficulty levels (Table 2).

In the language area, the assessed components are phonology and pragmatics, semantics, and syntax (morphosyntax). As well as in the cognitive area, some items are repeated, with increased demands as the age group progresses.

For the phonology and pragmatics ${ }^{1}$ component, the texts used are included in the Costa Rican Ministry of Public Education curricula ${ }^{19}$, which shows excellent language skills discrimination quotients. Similarly, a wordlist asking for the definition of each item is a relevant item to assess semantics ${ }^{15,16}$ as a language skill, as the pilot (Table 3) showed high percentages of positive answers (above 85\%), with excellent discrimination quotient values. For such reasons, the research group decided to keep it during the whole test.

Syntax (morphosyntax), understood as the close relationship between word structure and statement
Table 3. Discrimination quotient and difficulty level results of language items by age in the EVADE test

\begin{tabular}{|c|c|c|c|c|c|c|c|}
\hline \multicolumn{4}{|c|}{ First collection } & \multicolumn{4}{|c|}{ Second collection } \\
\hline $\begin{array}{l}\text { Area/ } \\
\text { item }\end{array}$ & dl & deq & SD & $\begin{array}{c}\text { Area/ } \\
\text { item }\end{array}$ & dl & deq & SD \\
\hline \multicolumn{8}{|c|}{6 years- 6 years 11 months 29 days } \\
\hline LG.1 & 0.99 & 0.04 & 0.10 & LG.1 & 1 & 0 & 0 \\
\hline LG.2 & 0.97 & 0.27 & 0.17 & LG.2 & 1 & 0 & 0 \\
\hline LG.3 & 0.80 & 0.47 & 0.40 & LG.3 & 0.10 & 0.16 & 0.31 \\
\hline \multicolumn{8}{|c|}{7 years- 7 years 11 months 29 days } \\
\hline LG.1 & 0.93 & 0.59 & 0.26 & LG.1 & 1 & 0 & 0 \\
\hline LG.2 & 0.98 & 0.12 & 0.14 & LG.2 & 0.38 & 0.14 & 0.49 \\
\hline LG.3 & 0.90 & 0.43 & 0.30 & LG.3 & 0.79 & 0.27 & 0.41 \\
\hline \multicolumn{8}{|c|}{8 years-8 years 11 months 29 days } \\
\hline LG.1 & 0.95 & 0.08 & 0.22 & LG.1 & 0.90 & 0.60 & 0.30 \\
\hline LG.2 & 0.76 & 0.65 & 0.43 & LG.2 & 0.86 & 0.53 & 0.36 \\
\hline LG.3 & 0.66 & 0.51 & 0.48 & LG.3 & 0.81 & 0.57 & 0.40 \\
\hline \multicolumn{8}{|c|}{9 years -9 years 11 months 29 days } \\
\hline LG.1 & 0.62 & 0.67 & 0.49 & LG.1 & 0.62 & 0.64 & 0.49 \\
\hline LG.2 & 0.83 & 0.67 & 0.38 & LG.2 & 0.74 & 0.21 & 0.44 \\
\hline LG.3 & 0.95 & 0.34 & 0.22 & LG.3 & 0.97 & 0.29 & 0.17 \\
\hline \multicolumn{8}{|c|}{10 years-11 years 11 months 29 days } \\
\hline LG.1 & 0.75 & 0.42 & 0.43 & LG.1 & 0.83 & 0.81 & 0.41 \\
\hline LG.2 & 0.84 & 0.59 & 0.36 & LG.2 & 1 & 0 & 0 \\
\hline LG.3 & 0.72 & 0.44 & 0.44 & LG.3 & 1 & 0 & 0 \\
\hline \multicolumn{8}{|c|}{12 years-13 years 11 months 29 days } \\
\hline LG.1 & 0.74 & 0.52 & 0.44 & LG.1 & 1 & 0 & 0 \\
\hline LG.2 & 0.97 & 0.41 & 0.17 & LG.2 & 1 & 0 & 0 \\
\hline LG.3 & 0.77 & 0.36 & 0.42 & LG.3 & 0.67 & 0.52 & 0.52 \\
\hline
\end{tabular}

LG: language items; dl: difficulty level; deq: discriminatory effectiveness quotient; SD: standard deviation.

formation ${ }^{20}$, is assessed with items where phrases are put in order or through a narrative. The proposed items keep a high difficulty level throughout the test and excellent discrimination quotients, providing enough validity to screen language skills in school-age children and adolescents (Table 3).

The social-affective area analysis includes statistical data and the leading suggestions from the groups of experts. Statistical findings (Table 4) show that all statements reached difficulty levels over $65 \%$, and 
Table 4. Discrimination quotient and difficulty level results of social-affective items by age in the EVADE test

\begin{tabular}{|c|c|c|c|c|c|c|c|}
\hline \multicolumn{4}{|c|}{ First collection } & \multicolumn{4}{|c|}{ Second collection } \\
\hline $\begin{array}{l}\text { Area/ } \\
\text { item }\end{array}$ & dl & deq & SD & $\begin{array}{c}\text { Area/ } \\
\text { item }\end{array}$ & dl & deq & SD \\
\hline \multicolumn{8}{|c|}{6 years- 6 years 11 months 29 days } \\
\hline SA.1 & 0.75 & 0.47 & 0.44 & SA.1 & 0.75 & 0.63 & 0.44 \\
\hline SA.2 & 1 & 0 & 0 & SA.2 & 1 & 0 & 0 \\
\hline SA.3 & 0.97 & 0.29 & 0.17 & SA.3 & 1 & 0 & 0 \\
\hline \multicolumn{8}{|c|}{7 years- 7 years 11 months 29 days } \\
\hline SA.1 & 0.86 & 0.22 & 0.35 & SA.1 & 0.90 & 0.72 & 0.31 \\
\hline SA.2 & 1 & 0 & 0 & SA.2 & 0.97 & 0.25 & 0.16 \\
\hline SA. 3 & 0.98 & 0.21 & 0.14 & SA. 3 & 0.97 & 0.78 & 0.16 \\
\hline \multicolumn{8}{|c|}{8 years-8 years 11 months 29 days } \\
\hline SA.1 & 0.97 & 0.13 & 0.17 & SA.1 & 0.90 & 0.57 & 0.30 \\
\hline SA.2 & 0.98 & 0.52 & 0.14 & SA.2 & 0.95 & 0.82 & 0.22 \\
\hline SA.3 & 0.99 & 0.04 & 0.10 & SA.3 & 1 & 0 & 0 \\
\hline \multicolumn{8}{|c|}{9 years -9 years 11 months 29 days } \\
\hline SA.1 & 0.98 & 0.42 & 0.14 & SA.1 & 1 & 0 & 0 \\
\hline SA.2 & 0.97 & 0.23 & 0.17 & SA.2 & 1 & 0 & 0 \\
\hline SA.3 & 0.99 & 0.35 & 0.10 & SA.3 & 1 & 0 & 0 \\
\hline \multicolumn{8}{|c|}{10 years-11 years 11 months 29 days } \\
\hline SA.1 & 0.85 & 0.30 & 0.35 & SA.1 & 0.67 & 0.97 & 0.52 \\
\hline SA.2 & 1 & 0 & 0 & SA.2 & 1 & 0 & 0 \\
\hline SA. 3 & 0.98 & 0.17 & 0.13 & SA. 3 & 0.83 & 0.81 & 0.41 \\
\hline \multicolumn{8}{|c|}{12 years-13 years 11 months 29 days } \\
\hline SA.1 & 0.89 & 0.45 & 0.31 & SA.1 & 0.67 & 0.93 & 0.67 \\
\hline SA.2 & 1 & 0 & 0 & SA.2 & 1 & 0 & 1 \\
\hline SA. 3 & 0.98 & 0.09 & 0.14 & SA.3 & 0.83 & 0.38 & 0.83 \\
\hline
\end{tabular}

SA: social-affective items; dl: difficulty level; deq: discriminatory effectiveness quotient; SD: standard deviation.

discrimination quotients fluctuating between poor, good, and excellent, showing that this is an area with middle and low difficulty level statements, and poor social-affective traits detecting skills. However, qualitative data issued by experts and the research group's experience showed the importance of keeping all statements in the area to pay special attention to the answers of children and adolescents, as they are laden with information about their personal, family, scholar, peer groups, and community situation. It is deemed appropriate to delve into ideal behaviors to assess emotional and social skills, self-esteem, self-identity, and other components vital for population groups such as school-age children and early-stage adolescents in later studies.

To bring this discussion to an end, it is restated that the intention of every development test assessment process is to allow parents, teachers, or other school agents, and especially health professionals the most complete possible information about the abilities and limitations of children and adolescents, to be prepared and generate more effective and early intervention spaces and measurements.

The main limitation of this research was the duration of the data collection process. To obtain just the face validity is not enough when talking about developmental assessment tests. Therefore, it will be necessary to continue with validation processes to acquire sensitivity, specificity, and predictive values.

It is essential to mention that one of the main achievements of this study was the incorporation of the EVADEII test in the child protection public policy, more precisely in the Health Ministry's CEN-CINAI Program Operating Manual ${ }^{21}$ and the Costa Rican Social Security Fund's Child Health Comprehensive Care Manual22.

The success of every instrument that seeks to detect possible developmental problems pertinently resides in its belonging to a development monitoring system. Such a system must preferably be designed and executed from a public policy framework in agreement with a nation's health and instruction services.

The EVADE-II test, as a screening tool, requires subsequent validation processes with the purpose of improving specific areas, such as motor skills and social-affective development, and to keep the rest of the areas updated.

\section{Ethical disclosures}

Protection of human and animal subjects. The authors declare that the procedures followed were in accordance with the regulations of the relevant clinical research ethics committee and with those of the Code of Ethics of the World Medical Association (Declaration of Helsinki).

Confidentiality of data. The authors declare that they have followed the protocols of their work center on the publication of patient data.

Right to privacy and informed consent. The authors have obtained the written informed consent of the patients or subjects mentioned in the article. The corresponding author is in possession of this document. 


\section{Conflicts of interest}

The authors declare that they have no conflicts of interest in this study.

\section{Funding}

None.

\section{Acknowledgments}

The authors would like to thank all of those who collaborated in the research project (professors at the Nursing School) and to the Programa de Investigación de Enfermería (PROINE).

\section{References}

1. Guevara-Montoya S, Quezada-Ugalde AM, Solís-Cordero K, Baldi-Zúñiga C. Proceso de Validación de la Prueba General de Desarrollo de Los Niños, Niñas y Adolescentes Entre los 6 y 14 Años de Edad, Dissertation. Costa Rica: Universidad de Costa Rica; 2011.

2. Rizzoli-Córdoba A, Delgado-Ginebra I. Pasos para transformar una necesidad en una herramienta válida y útil para la detección oportuna de problemas en el desarrollo infantil en México. Bol Med Hosp Infant Mex. 2015;72:420-8.

3. León-Sáenz AT. Desarrollo y Atención del Niño de 0 a 6 Años. Costa Rica: EUNED; 2002

4. Baena A, Granero A, Ruiz PJ. Procedimientos e instrumentos para la medición y evaluación del desarrollo motor en el sistema educativo. J Sport Health Res. 2010;2:63-76.

5. Papalia DE, Duskin-Feldman R, Martorell G. Desarrollo Humano. Mexico City: McGraw-Hill/Interamericana Editores; 2012.

6. UNICEF. La Adolescencia Temprana y Tardía. UNICEF Report. Mexico: UNICEF; 2011. Available from: https://www.unicef.org/spanish/sowc2011/ pdfs/La-adolenscencia-temprana-y-tardia.pdf.
7. Hernández-Sampieri R, Fernández-Collado C, Baptista-Lucio P. Metodología de la Investigación. Mexico: McGraw-Hill; 2010.

8. Alcantud-Marín F, Alonso-Esteban Y, Rico-Bañón D. Validez y fiabilidad del Sistema de Detección Precoz de los Trastornos del Desarrollo: 3 a 36 meses. Rev Esp Discapac. 2015;3:107-21.

9. Polit D, Tatano Beck C, Hungler B, Thorell A. Fundamentos de Investigación en Enfermería: métodos, Evaluación y Utilización. Porto Alegre: Artmed; 2004

10. Universidad de Costa Rica. Reglamento Ético Científico de la Universidad de Costa Rica Para las Investigaciones en Las Que Participan Seres Humanos. La Gaceta Universitaria; 2000. p. 1-6. Available from: http:// www.cu.ucr.ac.cr/normativ/etico_cientifico.pdf.

11. Ortiz-Romero GM, Díaz-Rojas PA, Llanos-Domínguez OR, Pérez-Pérez SM, González-Sapsin K. Dificultad y discriminación de los ítems de examen de metodología de la investigación y estadística. EDUMECENTRO (Cuba). 2015;7:19-35.

12. Gutiérrez-Martínez F. Teorías del Desarrollo Cognitivo. Madrid: McGraw-Hill/Interamericana de España; 2005.

13. Cofré JA, Tapia AL. Cómo Desarrollar el Razonamiento Lógico Matemático: manual Para Kínder a Octavo Básico. Santiago de Chile: Editorial Universitaria; 2003.

14. Palacios MG, Guajardo E, Cárdenas M, Maldonado H. Prueba Monterrey. Mexico: Secretaría de Educación Pública (SEP); 1981.

15. Terman LM, Merrill MA. Prueba de Inteligencia: Terman Merril. $3^{\text {rd }}$ Revision from the 1960 Version. Madrid: Formas L y M; 1975.

16. Weschsler D. Test de Inteligencia Para Preescolares (WPPSI): manual de Administración y Puntuación. New York: The Psychological Corporation; 1967.

17. Reyes S, Barreyro JP, Injoque-Ricle I. Evaluación de componentes implicados en la función ejecutiva en niños de 9 años. Panam J Neuropsychol. 2014;8:44-59.

18. Reforma de la Educación Matemática en Costa Rica. Distribución de Conocimiento en la Implementación de los Programas de Matemáticas Para la Enseñanza Primaria. Algunas Sugerencias. Costa Rica: Ministerio de Educación Pública, Fundación para la Cooperación (CRUSA); 2014. Available from: https://www.mep.janium.net/janium/Documentos/11277.pdf.

19. Programa de estudio de español: primer Ciclo de la Educación General Básica. Alajuela: Ministerio de Educación Pública; 2013.

20. King LD, Suñer M. Gramática Española: análisis y Práctica. USA: Waveland Press Inc.; 2008.

21. Villalobos-Hernández E, Song-Morales M, Ramírez-Carranza I, Montero-Salguero C. Modelo operativo del Sistema de Vigilancia del Estado Nutricional y del Desarrollo Infantil (SISVENDI). San José: Ministerio de Salud; 2012.

22. Costa Rican Social Security Fund. Manual de Procedimientos Para la Atención Integral del Niño y la Niña. Primer Nivel de Atención. San José: Child Attention Normalization Program; 2016. 